\title{
EXT1 Gene
}

National Cancer Institute

\section{Source}

National Cancer Institute. EXT1 Gene. NCI Thesaurus. Code C18251.

This gene plays a role in heparin/heparin sulfate biosynthesis, axon guidance and biogenesis/cell organization. 